\title{
MODERN TUTORIAL APPROACHES AT UNIVERSITIES: THEORETICAL AND PRACTICAL ASPECTS
}

Actuality of the paper is highlighted with the feature that the modern world of education has long shifted the focus of its teaching approach from mostly teacher-centered classroom atmosphere or often claimed as conventional way of teaching to a more learner-centered teaching.

To be more specific, higher education is an indispensable part of any modern society, that is undergoing drastic changes because of different factors such as emerging technology innovation, student mobility, and government regulations. Keeping in mind the fact that modern educational university process are facing stiff pressure because of the high cost of books, low cost interactive web-based courses, and invasion of information technologies, updated trends are to be implemented in order to reach learners' high results and accomplishments.

The provided modern survey has comprised three interrelated and logically-structured sections. Introducing clarifications, the first theoretical section of the paper was dedicated to giving four basic important features of the learner-centered approach application at modern universities; the findings of the second theoretical section are devoted to the explanation of ten characteristics of student-centered Learning (according Jack C. Richards) and the third, practical section is related to presenting and exemplifying learner-centered assignments in form of proverbs and sayings that can be implemented in the educational process at universities.

The research findings have been claimed that learner-centered teaching at universities tends to promote inductive learning, and, consequently, modern students becomes the active agents in the learning process who are in charge of the learning while the teacher becomes a mere facilitator of that learning. It was noted that one of the main features of this approach is that learners' autonomy is promoted, increasing, at the same time, the efficiency of professional competences acquisition.

Key words: modern education, learner-centered approach, advantages, characteristics, English teaching process, students, universities, proverbs and sayings.

\section{(статтю подано мовою орихіналу)}

This research was initiated by the urgent, actual social problems educators face on a daily basis in the period of constant changes, globalization process, innovations and information overload. While traditional methodologies such as the audio-lingual and direct methods still offer useful elements, they're clearly outdated in the modern classroom. The communicative approach, which was in vogue in the late ' $90 \mathrm{~s}$, is still widely considered as the latest advancement in modern language teaching. Most TESOL/TEFL training programs still live and swear by it. However, it has become clearly evident that the needs of modern students have outpaced teachers' and book publishers' best strategies [5; 7;9].

Every year we are seeing a change of trends in almost all sectors and the case is no different in the field of education. This is one of the areas we see a lot of remarkable changes every year. It makes serious impacts on a student's perspective on education and the learning outcomes. It depends on a lot of factors including available resources, what options are affordable for a larger society and the changing needs or demands of the present generation students. Education trends are dynamic in nature $[12 ; 13 ; 14]$.

The biggest challenge for any teacher today is capturing each student's attention, and conveying ideas effectively enough to create a lasting impression. To our mind, to tackle this challenge effectively, modern education should implement innovative ideas that make the classroom experience much more lovable for students. Though there are different ways of teaching, so they can be divided into two broad categories: the teacher-centred way and the learnercentred one. For centuries, the former has been the norm at universities, but things seem to have gradually changed in the last two or three decades.

With regard of the problem actuality stated at the beginning of our research, we can identify the main purposes of the survey that are: the first theoretical section of the paper is dedicated to giving four basic important features of the learner-centred approach application at modern universities; the findings of the second theoretical section are devoted to the explanation of ten characteristics of student-centered Learning (according Jack C. Richards) and the third, practical section is related to presenting and exemplifying learner-centered assingments in form of proverbs and sayings that can be implemented in the English learning process at universities.

The investigation of the first theoretical section of the paper starts from the revealing four advantages of learnercentered education at universities.

First Advantage. The authenticity of language content and materials in the classrooms. According to David Nunan, a key aim of a learner-centre curriculum is to use authentic materials in order "to generate classroom activities which simulate genuine communication in the classroom in the hope that this will facilitate transfer of learning" from classroom to outside or real world- second language use. And David Nunan insists on the fact that this authenticity "should relate to the text sources as to student activities and tasks $[5 ; 8 ; 11]$.

Second Advantage. Language content's appropriateness to the learners' needs and interests. Though it is true that, as Alan Maley writes, in many of the classrooms with which most of us are familiar "it is normal and expected 
that teachers will make most, if not all, of the decisions about the teaching content and materials", we now know that students learn best when they become engaged in activities or tasks in which they have to use the target language, so learners' communicative needs are a priority in the learner-centred approach. According to K. Jennings and Tom Doyle, in a learner-centred approach, learners' needs (classified in terms of real-life tasks and learning style preferences) form the centre of the teacher's planning process" $[4 ; 7 ; 11]$.

Third Advantage. Learners' active role in the learning process. The learner becomes the active agent in the learning process and he or she takes charge of the learning while the teacher becomes a mere facilitator of that learning. As A. McLean points out, "Learning is most effective when the learner is the initiator of the learning process". Classes are dynamic and learner-centred teachers try to involve learners in the organisation and development of different activities, and learners are frequently invited to experiment with the English by using it in writing and talking as much as possible. Recent research into the nature of learning has put special emphasis precisely on the active role learners must play in the learning process $[7 ; 8 ; 11]$.

Fourth Advantage. Learners' autonomy. One of the main features of this approach is that learners' autonomy is promoted, and learners are made responsible for their own learning. According to J. Taylor, "A certain degree of autonomy is always worth encouraging because it raises motivation and speeds up progress". H. Holec is in favour of teaching anguage learners to learn, because, as he puts it, that "is considered the best way of ensuring that learning takes place". Also, Rebecca Oxford points out: "When students take more responsibility, more learning occurs, and both teachers and learners feel more successful" [8;10;11].

Furthermore, we are going to provide the findings of the second theoretical section which are devoted to the explanation of ten characteristics of student-centered Learning. In addition, these are some of the views that Jack C. Richards about student-centered learning and teaching [3].

Characteristic\#1. Students work harder than their teachers. In most classes, teachers are doing too many learning tasks for students: ask the questions, add detail to their answers, offer the examples, organize the content, do the preview and the review. As a result, Jack C. Richards recommends to extend part of those responsibilities to the learners $[3 ; 5]$.

Characteristic \#2. Students learn from Classmates. Students can learn from and with each other. Certainly the teacher has the expertise and an obligation to share his/her knowledge, but teachers can learn from students as well $[3 ; 8]$.

Characteristic \#3. Students learn more by experiences and active involvement. Teachers nurture students' natural curiosity as students ask questions to complete the assignments [3; 7].

Characteristic \#4. Students apply new learning to real-life, authentic experiences. Jack C. Richards considers that classes focus more on skills that you can use in real-life, because the ones that don't have real-life application hardly ever motivate students to engage in meaningful learning $[3 ; 4]$.

Characteristic \#5. Students receive frequent directed, and timely feedback. Another characteristic of studentcentered learning and teaching at universities is that as students complete some assignments, teachers typically ask learners or groups of learners to talk and compare their results with peers $[3 ; 6]$.

Characteristic \#6. Students are encouraged to explain material to themselves and others. Jack C. Richards confident that if students are creative enough, they can think about ways to introduce a topic that involves the students in the process $[3 ; 12]$.

Characteristic \#7. Students regularly engage in communication. Students need to communicate with each other and that's why this approach to teaching bring more benefit than teacher-centered instruction. University learners can introduce a topic, receive feedback from others and complete assignments collaboratively [3; 14$]$.

Characteristic \#8. Students know what they are learning and why. Jack C. Richards states that the teachers who have adopted a learner-centered approach state

what they expect their learners to accomplish by the end of the class and make sure they give clear instructions about the behavior and dynamics he/she expects to see in class $[3 ; 11]$.

Characteristic \#9. Students use personalized technology to produce. Students learn by doing so technology, specially mobile phones and tablets which are easier to handle and use than computers can really boost engagement and motivation. Jack C. Richards advices to use the resources available on the internet if we want our students to create $[3 ; 9]$.

Characteristic \#10. A higher degree of engagement. Students standing up and talking to others to complete some assignments creates more opportunities to talk and learn from others. Since receptive skills are the ones necessary to learn new things, listening to others is crucial for the successful repetition of new vocabulary [3; 8].

In overall, taking into consideration the material of two theoretical sections, we are going to present the third, practical section which is related exemplifying learner-centered assingments in form of proverbs and sayings that can be implemented in the English learning process at universities.

The main merit of the proverbs and sayings as a unique branch of the people culture is that the reflect national frame of mind, mentality, and embodies original features of another language perception of the reality. Proverbs, saying, figurative comparisons are constituents of the culture, valuable treasure of the people, as they improve the language of the new generations. They are mainly brief aphoristic artistically expressive expressions-observations about different phenomena and life situations $[12 ; 14]$. 
The significance of knowing and using them in everyday speech is undoubtedly very important. Therefore, using proverbs, sayings and patters during the lessons can help to diversify lessons, this activity will help to develop speaking skills. Such brief literature forms as proverbs successfully train different aspects of the language, i.e. pronunciation, grammar, vocabulary and critical thinking. They are wise and considerable in lexical meaning. They are not difficult to remember because of consonance, rhythm; they are distinct and expressive, they demand activation of figurative thinking and analysis; and they can help to illustrate the point of view of a speaker, and to generalize it in a brief form $[12 ; 13]$.

Proverbs reflect all aspects of life, needs, customs, habits, traditions, attitude to the nature. They are inherent part of people's way of life, language and literature. Due to these features proverbs and saying are easily integrated in the process of the lesson. Exercises on their basis do not need too much time for preparation, and also they help to bring an element of play of different stages of English learning.

There are some variants of using proverbs as exercises, e.g. some proverbs can be given for learning. Students can explain the meaning of them using their own words, and choose the proper variants of the native equivalents; and then they can be given a task to make up stories or dialogues the main idea of which must be these proverbs. At this time students interact with each other working in pairs or groups creating their stories or dialogues. The selection of the proverbs will stimulate students to express their point of view $[9 ; 12 ; 14]$.

Using proverbs and sayings in language learning is very productive from the point of view of cognitive skills development. Learning sayings and proverbs students enrich their vocabulary with new words and set-expressions which in further learning of the language can be used as active vocabulary. The task to write compositions or miniessays is one of the efficient methods of teaching writing. Students can be given proverbs to illustrate a certain life situation. Such activities induce positive emotions, heightens motivation for learning. Proverbs, saying and patters is such an instrument of teaching a foreign language which activates mental activity and has a significant methodological and practical value in the process of learning. They make the teaching process more interesting as they stimulate emotional development of students' personality which forms mighty stimulus for learning the language [10;12].

There is a huge amount of proverbs in the English language, some of them are presented in the table 1 [14].

List of Famous English Proverbs and Sayings

Table 1

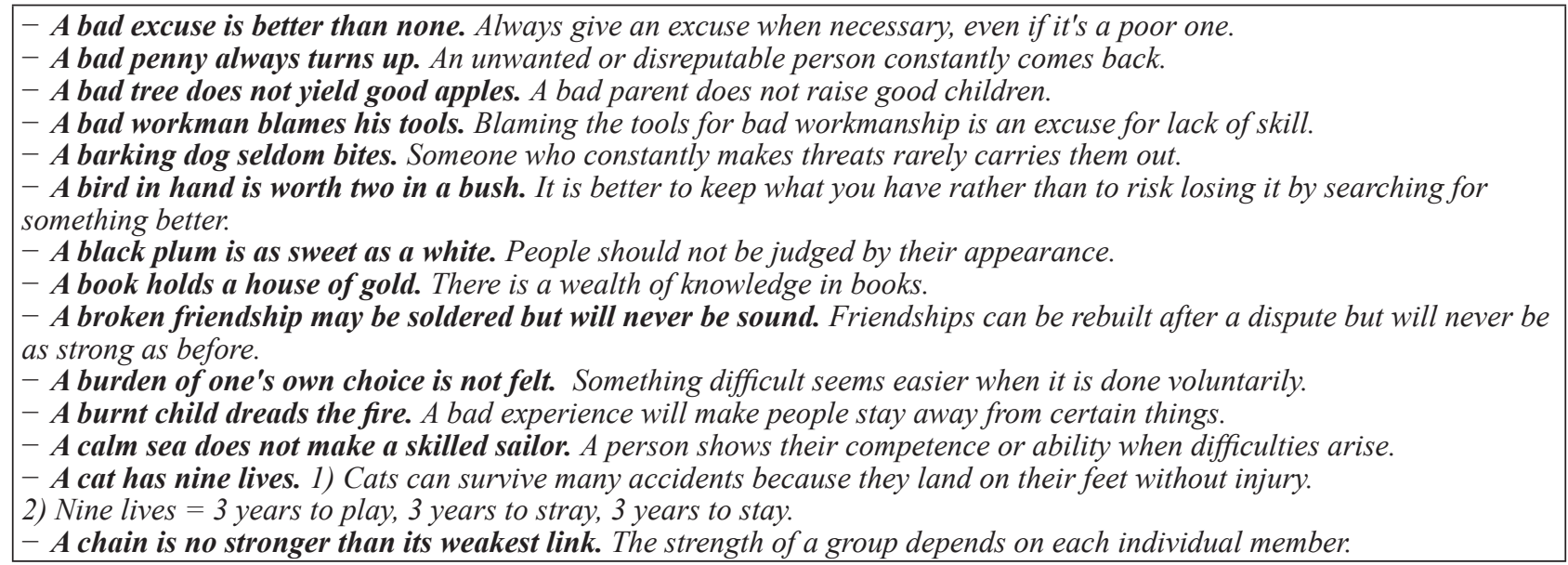

Hereby, usage of proverbs and sayings adds to the educative process a communicative direction, strengthens motivation of language learning and significantly improves the quality of mastering speaking and writing skills. It is a substantial stage for psychological adaptation of students in a new speech space.

To sum up, over the past decades, there has been a gradual shift from a teacher-centred to a learner-centered approach. This approach to teaching English has been increasingly being encouraged in higher education over the past decades in developed European countries. Moreover, the results of our survey has witnessed that the learnercentred approach in higher education is more effective than the teacher-centred approach for a number of reasons: firstly because what is taught is not necessarily learnt so teachers need to be able stir students' interest for learning. This can only be achieved if the focus in on the students' needs not on the teachers constraints.

Secondly, education process of mastering students' competences is more feasible because language learning involves skill development, not only knowledge transmission so teachers should focus on ways to develop students' ability to use them effectively in real-life contexts rather than their ability to simply "reproduce" it.

Finally, it aims at developing students' awareness of themselves as learners and it consequently enables them to figure out what their best learning strategies are.

From our perspective, the future surveys in the concern of modern teaching approaches implementation can be streamlined into finding out key facts and ideas dealt with some of the major trends in education technology for the modern society. 
Bibliography:

1. Ardi Marwan. Implementing Learner-Centered Teaching in an English Foreign Language (EFL) Classroom. A Journal of Culture, English Language Teaching and Literature. 2017. Vol. 17. P. 45-59.

2. Cozma M. The Challenge of Teaching English to Adult Learners in Today's World. Procedia - Social and Behavioral Sciences. 2015. Vol. 197. P. 1209-1214.

3. Characteristics of Student-Centered Learning: web-site. URL: https://englishpost.org/student-centered-learning/.

4. Jones L. The Student-Centered Classroom. Cambridge : Cambridge University Press, 2007. P. 17-28.

5. Learner-Centered Approach in Language Teaching: web-site. URL: https://library.iated.org/view/shamsutdinova2014lea.

6. Learning English Today: web-site. URL: https://www.learn-english-today.com/resources-for-teachers.html.

7. Matukhin D., Bolgova D. Learner-centered Approach in Teaching Foreign Language. Psychological and Pedagogical Conditions: Procedia - Social and Behavioral Sciences. 2015. Vol. 206. P. 148-155

8. Meece J. L. Applying Learner-Centered Principles to Middle School Education. Theory into Practice. 2003. № 42 (2). P. $109-116$.

9. Merriam, Caffarella S. B., Baumgartner R. S. Learning in adulthood: a comprehensive guide. 3rd ed. San Francisco : Jossey-Bass, 2007. $533 \mathrm{p}$.

10. Nakamura K. Creating a Learner-centered Communicative Classroom for Student Teachers. The Journal of the Institute for Language and Culture. 2005 Volume 9. P. 1-20.

11. Sánchez C. A. A Learner-Centred Approach to The Teaching of English as an L2. ES. 2007. Vol. 28. P. $189-196$.

12. Proverbs, Saying and Patters in Teaching English: web-site. URL: http://www.kamts1.kpi.ua/sites/default/files/files/04_\%20 Proverbs, $\% 20$ saying.

13. Teaching adult students: web-site. URL: https://eric.ed.gov/?id=ED395136.

14. Tribble C. Managing Change in English Language Teaching. Lessons from Experience. 2012. Vol. 23. P. $179-187$.

\section{References:}

1. Ardi Marvan. Vprovadzhennya navchannya, oriyentovanoho na uchnya, v klasi anhliyskoyi inozemnoyi movy (EFL). Zhurnal kultury, vykladannya anhliyskoyi movy ta literatury. 2017. Tom 17. S. 45-59. DOI: 10.24167/celt.v17i1.1138.

2. Kozma M. Problema vykladannya anhliyskoyi movy dlya doroslykh uchniv u suchasniy svitoviy protsesiyi - sotsialni ta povedinkovi nauky. 2015. Tom 197P. 1209-1214. DOI: 10.1016 / jsbspro.2015.07.380.

3. Kharakterystyka navchannya, oriyentovanoho na studentiv: veb-sayt. URL: https://englishpost.org/student-centered-learning/.

4. Dzhons L. Klas, oriyentovanyy na uchniv. Kembrydzh : Kembrydzhskyy universytetsky pres. 2007. S. 17-28.

5. Pidkhid, oriyentovanyy na navchannya, u navchanni movy: veb-sayt. URL: https://library.iated.org/view/shamsutdinova2014lea. DOI: 10.1016 / j.sbspro.2015.10.044

6. Vyvchennya anhliys'koyi movy sohodni: veb-sayt. URL: https://www.learn-english-today.com/resources-for-teachers.html.

7. Matukhin D., Bolhova D. Pidkhid do navchannya inozemnoyi movy, oriyentovanyy na navchannya. Psykholohichni ta pedahohichni umovy: Protsediya - sotsialni ta povedinkovi nauky. 2015 rik. Tom 206. S. 148-155.

8. Meece J. L. Zastosuvannya pryntsypiv, oriyentovanykh na uchniv, do serednoyi shkoly. Teoriya na praktytsi. 2003. 42 (2). S. 109-116.

9. Merriam, Kaffarela S. B., Baumhartner R. S. Navchannya v doroslomu vitsi: vycherpnyy posibnyk (3-e vydannya). SanFrantsysko: Dzhossi-Bas. 2007. 533 s.

10. Nakamura K. Stvorennya komunikatyvnoyi audytorial'noyi audytoriyi dlya vchyteliv uchniv, oriyentovanoyi na uchnya. Zhurnal Instytutu movy ta kul'tury. 2005. Tom 9. S. 1-20.

11. Sanches S.A. Pidkhid, oriyentovanyy na uchnya, do vykladannya anhliys'koyi movy yak L2. ES. Tom 28.2007. S. 189-196.

12. Pryslivya, prykazky ta malyunky u vykladanni anhliyskoyi movy: veb-sayt. URL: http://www.kamts1.kpi.ua/sites/default/files/ files/04 \%20Proverbs, $\% 20$ saying.

13. Navchannya doroslykh studentiv: veb-sayt. URL: https://eric.ed.gov.

14. Tribble C. Upravlinnya zminamy v navchanni anhliyskoyi movy. Uroky dosvidu. 2012. Vyp. 23. S. 179-187.

\section{Василичина Н. М. Сучасні навчальні підходи університетів: теоретичні та практичні аспекти}

Актуальність дослідження підкреслюється тим фактом, що вища освіта, включаючи сфери навчання й викладання англійської мови, уже давно змістила фокус викладацького підходу з атмосфери класу, орієнтованої переважно на вчителя, інакше кажучи, традиційного способу викладання на особистісно-орієнтоване та індивідуалізоване навчання.

Якщчо бути більш конкретним, вища освіта є невід'ємною частиною будь-якого сучасного суспільства, яке зазнає кардинальних змін через різні фактори, такі як нові технології, інноващії, мобільність студентів та урядові постанови. 3 огляду на той факт, щчо сучасний навчальний університетський проиес стикається з низкою проблем, серед яких висока вартість книг, низькі затрати на інтерактивних вебкурсах і швидке впровадження інформаційних технологій, варто впроваджувати оновлені тендениії, щуоб студенти демонстрували високі результати й досягнення.

Наведене сучасне дослідження складається з трьох взаємопов'язаних і логічно структурованих розділів. Отже, перший теоретичний розділ статті присвячений опису чотирьох основних важливих особливостей застосування особистісно-зорієнтованого підходу в сучасних університетах; розвідки другого теоретичного розділу присвячені поясненню десяти характеристик особистісно-зорієнтованого підходу (за Джеком К. Річардсом), а третій, практичний, розділ безпосередньо пов'язаний із розробленням завдань у формі прислів 'ї і приказок, щуо можуть бути реалізовані в навчальному прочесі в університетах.

Результати дослідження стверджують, щео особистісно-зорієнтований підхід сприяє індуктивному навчанню в університетах, у проиесі якого студенти вишів стають активними учасниками в навчальному прочесі, водночас беручи на себе відповідальність за навчання, тоді як викладач виступає в ролі фасилітатора иього навчання. Відмічено, щзо однією з головних особливостей такого підходу є те, щзо автономія студентів сприяє підвищенню рівня сформованості професійних компетентностей.

Ключові слова: сучасна освіта, особистісно-зорієнтований підхід, переваги, характеристики, процес оволодіння англійською мовою, студенти, університети, прислів'я та приказки. 